\title{
ポリマーセメントモルタルライニングの塩化物遮蔽性能と耐久性 \\ CHLORIDE SHIELDING PERFORMANCE AND DURABILITY OF POLYMER MODIFIED MORTAR LINING FOR USE IN REINFORCED CONCRETE STRUCTURES EXPOSED TO MARINE ENVIRONMENTS
}

\author{
小林一輔*·大濱嘉彦**・星野富夫*** \\ By Kazusuke KOBAYASHI, Yoshihiko OHAMA and Tomio HOSHINO
}

\begin{abstract}
Reinforced concrete beam specimens with the polymer modified mortar linings using a mixture of acrylic and epoxy emulsions are prepared, and exposed to a severe marine corrosion environment, where the beam specimens are continuously subjected to seawater splashes, for five years. The chloride shielding performance and durability of the polymer modified mortar linings are examined through five-year exposure by chemical analysis and EPMA area analysis. It is concluded from the test results that the polymer modified mortar linings possess an excellent chloride shielding performance and durability because of the effective 3-layer lamination of the polymer modified mortar.
\end{abstract}

Keywords : corrosion protection, chloride shielding performance, polymer modified mortar, reinforced concrete beams, marine environment

\section{1.はしがき}

ポリマーセメントモルタルは塩害を受けた鉄筋コンク リート部材の補修材として, あるいは海洋環境に新設さ れる鉄筋コンクリート構造物の防食ライニングとして使 用されているが，その塩化物遮蔽効果については必ずし も明らかにされていない. 本論文は，ポリマーセメント モルタルライニングを施した鉄筋コンクリートはりを, 絶えず海水飛沫を受ける厳しい腐食環境下において 5 年 間にわたって暴露した結果 ${ }^{1), 2}$ に基づいて，1）ポリマー セメントモルタルライニングが優れた塩化物遮蔽性能を 有すること，2）優れた塩化物遮蔽性能はライニングの 積層施工が寄与している可能性が高いこと, などを明ら かにしたものである.

\section{2. 実験方法}

ポリマーセメントモルタルによってライニングを行っ たライニング供試体と, ライニングを行わない無処理供

* 正会員 工博 千葉工業大学教授 土木工学科 ( 个275 習志野市津田沼 2-17-1)

** 正会員 工博 日本大学教授 工学部 ( ₹963 郡山市田村町徳定字中河原 1 )

*** 正会員 東京大学生産技術研究所技術官 第 5 部 （テ106＼cjkstart港区六本木 7-22-1）
試体の 2 種類の鉄筋コンクリート供試体を，海水飛沫を 絶えず受ける海洋環境に 5 年間にわたって暴露した。供 試体の暴露期間中に, 各種の試験や分析を行って, ポリ マーセメントモルタルライニングの塩化物の遮蔽効果な らびに耐久性を検討した.

\section{（1）使用材料}

a) ライニング用ポリマーセメントモルタル

表一1に示すような材料を, 主材 : 混合液 A : 混合液 $\mathrm{B}=79: 17: 4$ (重量比) の配合で, 4 5 分間電動式攪 汼機でよく練りまぜてポリマーセメントモルタルを調製 した。これらの材料は，それぞれあらかじめ均一に混合 されたものである.この配合のポリマーセメントモルタ ルのポリマーセメント(ポルトランドセメント十高炉ス

表一1 ポリマーセメントモルタル用材料

\begin{tabular}{|c|c|c|c|}
\hline \multicolumn{2}{|c|}{ 主材 } & \multicolumn{2}{|l|}{ 混合液 A } \\
\hline 原 料 名 & 配合比(\%) & 原 料 名 & 配合比(\%) \\
\hline \multirow{2}{*}{$\begin{array}{c}\text { 普通ポルトラント } \\
\text { セメント } \\
\text { 高炬スラグ } \\
\text { 珪石粉 } \\
\text { 珪砂 }\end{array}$} & \multirow{3}{*}{$\begin{array}{l}25 \\
25 \\
20 \\
30\end{array}$} & $\begin{array}{l}\text { アクリル樹脂(全固形分:48\%) } \\
\text { エポキシ樹脂(全固形分: } 67.5 \% \text { ) }\end{array}$ & $\begin{array}{l}86 \\
14\end{array}$ \\
\hline & & \multicolumn{2}{|l|}{ 混 合 液 B } \\
\hline 補強材 & & 原 料 名 & 配合比(\%) \\
\hline \multicolumn{2}{|c|}{ ガラス緎維：経 $11 \mu$,長さ $6 \mathrm{~mm}$} & $\begin{array}{c}\text { ポリアミド樹脂(全固形分:50\%) } \\
\text { 水 }\end{array}$ & $\begin{array}{l}40 \\
60\end{array}$ \\
\hline
\end{tabular}


表一2 混合液Aのポリマーディスパージョンとしての性質

\begin{tabular}{|c|c|c|}
\hline $\begin{array}{c}\text { 比重 } \\
\left(20^{\circ} \mathrm{C}\right)\end{array}$ & $\begin{array}{c}\mathrm{p} \mathrm{H} \\
\left(20^{\circ} \mathrm{C}\right)\end{array}$ & $\begin{array}{c}\text { 粘度 } \\
\left(20^{\circ} \mathrm{C}, \mathrm{cP}\right)\end{array}$ \\
\hline 1.092 & 10.3 & 460 \\
\hline
\end{tabular}
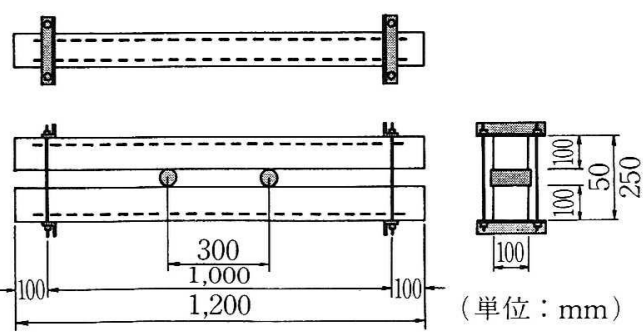

図一1 供試体の寸法と曲げ載荷固定方法（無処理はりの場合）

ラグ) 比は $24 \%$ である. 表一2には混合液 $\mathrm{A}$ のポリマー ディスパージョンとしての性質を示す.

b) コンクリート用材料

コンクリートの材料として, 普通ポルトランドセメン 卜, 大井川産の川砂 (F.M. 3.17, 比重 2.64, 吸水率 $0.15 \%$ ) および, 最大寸法 $15 \mathrm{~mm}$ (硬質砂岩, 比重 2.70, 吸水率 $0.47 \%$ ）の砕石を用いた。

コンクリートは, 水セメント比 $60 \%$, 細骨材率 $47 \%$ および単位セメント量 $327 \mathrm{~kg} / \mathrm{m}^{3}$ で，スランプが $8 \mathrm{~cm}$ になるように配合を定めた。

\section{（2）供試体の作製}

a）鉄筋コンクリート供試体の作製とライニングの施 I.

鉄筋コンクリート供試体は, $10 \times 10 \times 120 \mathrm{~cm}$ の矩形 はり供試体で, その内部に長さ $110 \mathrm{~cm}$, 公称直径 10 $\mathrm{mm}$ の異形棒鋼 2 本を埋め込んだもので, 鉄筋のかぶり が $2 \mathrm{~cm}$ と $3 \mathrm{~cm}$ の 2 種類を作製した.これらのはり供 試体はコンクリートの打ち込み後, 21 日間屋外で散水 養生を行ってから，ポリマーセメントモルタルライニン グを施し、ライニング供試体を作製した.ライニングは， コンクリートの打ち込み面を除く 5 面をワイヤブラシて ケレン清掃した後, 全厚さが約 $10 \mathrm{~mm}$ になるように, 3 層に分けて積層施工した。すなわち，まず最下層を施工 した 18 時問後に中間層を, その 24 時間後に最上層を施 エした.

b) 供試体の曲げ載荷固定方法

ライニングの施工を終了した後，すべてのはりを 2 本 1 組として図一1に示すように，3 等分点曲げ載荷状態 で固定し，そのままの状態で海洋暴露に供した。ひびわ れの導入にあたっては，無処理供試体では，支点間中央 部の曲げひびわ楅がその引張縁で $0.2 〜 0.3 \mathrm{~mm}$ にな るまで載荷し，また，ライニング供試体では，これと同 一の曲げ荷重によってひびわれを導入し，固定したもの
である.この場合, 無処理供試体の引張縁に $0.2 \sim 0.3$ $\mathrm{mm}$ のひびわれを発生させると同じ荷重を，ライニング 供試体に加えた場合のひびわれ発生状況は, 前者が複数 のひびわれを生ずるのに対して，後者ではライニング層 の表面において観察される限りにおいては1 2 本のひ びわれが発生する.このひびわれ幅は $0.3 \sim 0.5 \mathrm{~mm}$ 程 度で無处理供試体の表面に発生するひびわれに比べて多 少大きくなる，またこの場合，ライニングの下層と接す るコンクリート面にもやはり複数のひびわれが発生して おり，その中の最も大きいひびわれの幅は $0.1 \sim 0.2$ $\mathrm{mm}$ 程度である.このような現象は, ライニング材とし てのポリマーセメントモルタルの伸び能力がコンクリー トのそれに比べて格段に大きいために生じたものと考え られる。すすなわち，その幅がある限界以下のひびわ机は ライニングによって拘束されるが，これを越えるような 幅のひびわれを生じた部分にのみライニング層を貫通す るひびわれが生じることになる。また，ライニング供試

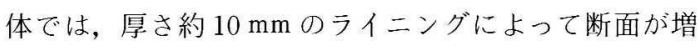
大するため, コンクリートの引張縁に生ずる引張応力度 は堿少するはずであるが，ライニング層のヤング率が小 さいために，その程度は比較的小さい，ライニング供試 体のコンクリート表面に生じているひびわれの大きさが 無処理コンクリートのそ机と大差がないのは，このよう な理由によるものと考えられる.

これらの供試体は各条件ごよに 3 組作製し，それぞれ 暴露期間 1 年, 3 年および 5 年で, 各種の試験および分 析に供した。

\section{(3) 暴露試験}

暴露試験は, 静岡県伊豆半島東海岸（伊東市城ケ崎） の岩場に設置した海洋暴露試験場において実施した。供 試体は写真一1に示すような最高潮位から約 $50 \mathrm{~cm}$ 程度 上部の架台に，打ち寄せる波の進行方向に平行になるよ うに固定した。この場所は，満潮時には波で洗われ，干 潮時にも, 前面に岩礁があるために, 絶えず海水飛沫を 受けるきわめて厳しい腐食環境下にある。したがって,

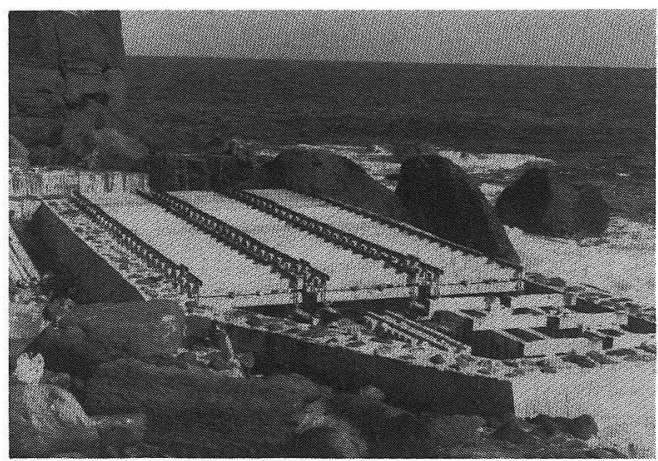

写真一 1 暴露試験場 
この環境は, JCI-SC 7「コンクリート供試体の暴露試 験場の環境区分に関する規準」における環境区分 $\mathrm{A}$ に該 当する。

\section{（4）試験方法および分析方法}

a）ひびわれなどの劣化性状の観察

供試体のひびわれの追跡や外観上の変状などを調べる ために，暴露期間 6 か月， $1 ， 2 ， 3 ４$ および 5 年の時点 で現地観察を行った. また, 暴露期間 1 年, 3 年および 5 年において, 供試体を暴露試験場より引き揚げて, 表 面の劣化状態やコンクリート中への塩分の浸透を調べる とともに, 供試体を解体し, 鉄筋の腐食位置と腐食状態 との関係を調べた.

b）鉄筋の腐食面積率と腐食度の測定方法

暴露期間 1 年, 3 年および 5 年で供試体を割裂し，鉄 筋の腐食位置をスケッチするとともに，鉄筋の腐食部分 をトレースし, 画像解析装置によって腐食面積を測定し て, 腐食面積率を求めた.この際の腐食面積測定の対象 となる鉄筋長は $110 \mathrm{~cm}$ とした。

著者らの一連の海洋暴露実験の結果 ${ }^{2}$ によれば，同一 腐食面積率でも腐食減量に相当な差があり, ある条件の ものは鉄筋に断面欠損を生じているものがあることが判 明している．このことから，鉄筋の腐食状態を定量的に 評価するために，腐食減量を腐食面積で除した値である 腐食度を用いることにした。この值は，平均腐食深さを 意味し，この值が小さいということは，腐食が鉄筋のご く表層部分に限定されていることを示している.

腐食量の測定は, JCI-SC 1 の「コンクリート中の鋼 材の腐食評価方法」を準用して, コンクリート中より取 り出した鉄筋を，10\%クエン酸二アンモニウム溶液 $\left(60^{\circ} \mathrm{C}\right)$ に 2 日間浸漬した後，ブラッシングによって 鉄筋表面の腐食生成物を除去して腐食減量を求めた。こ の際の基準となる腐食前の重量は，おのおのの鉄筋に よって大きく異なることから，供試体より取り出したお のおのの鉄筋の健全部分を約 $15 \mathrm{~cm}$ 切断して重量を正 確に測定し，全長の鉄筋の重量を計算で算出した值を用 いたものである。また，上記溶液に鉄筋を浸漬した場合 には，健全部分の黒皮部分も溶出するため，その鉄筋の

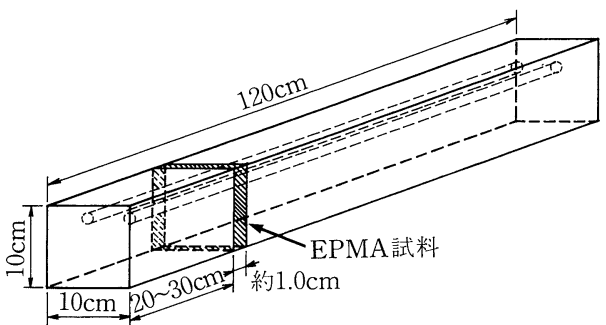

図一2＼cjkstart供試体における EPMA 試料の採取位置

腐食面積の割合で黒皮部分の重量補正を行った。これら の浸漬条件や黒皮部分の溶出量は，予備実験によって明 らかにした。

c）塩化物の分析方法

試料は, 直径 $30 \mathrm{~mm}$ のコンクリート用電動ドリルを 用いて，供試体表面から $10 \mathrm{~mm}$ 間隔で順に採取した。 分析は, JCI 基準「硬化コンクリート中に含まれる塩分 の分析方法」(案)に規定されている電位差滴定によって, 全塩素量を測定した。

d）EPMA による塩素および炭素の分析方法

供試体の全断面における塩素の分布を知るために，図 一2に示すような位置から, 厚さ約 $10 \mathrm{~mm}$ の試料を切 り出し, 試料の表面を研磨の後, 炭素蒸着を行い, EPMAによる面分析を行って調べた. 一方, 供試体の ライニング層における塩素および炭素の分布を知るため に，図一 8 に示すような位置から，ライニング層とコン クリート部分を含む, 表面から深さ約 $20 \mathrm{~mm}$ の部分に ついて, 厚さ約 $10 \mathrm{~mm}$ の試料を切り出し, 同様に EPMAによる面分析を行った。

e）ライニングの接着強度試験

建研式接着試験機を用いて，ライニング供試体のライ ニングとコンクリートとの接着強度を試験した．比較の ために, 無処理供試体についても, 同様の試験を行った.

f ) 酸素の拡散係数試験

ライニング供試体の表面から，ライニング層とコンク リート部分を含む厚さ約 $20 \mathrm{~mm}$ の部分について, 約 10 $\times 10 \mathrm{~cm}$ の試料を切り出し, JCI-DD 5 「酸素の拡散係 数試験方法」(案) に準じて, 試料の酸素の拡散係数を

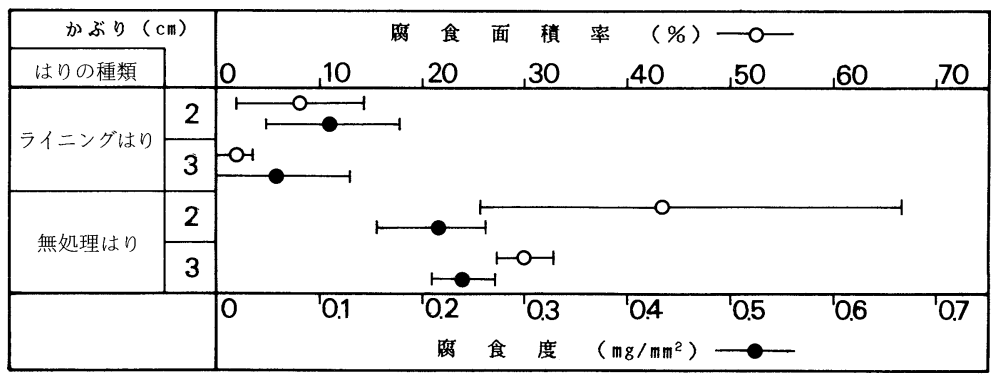

図一3 鉄筋の腐食面積率と腐食度（海洋暴露 5 年の場合） 
測定した。

\section{3. 実験結果と考察}

\section{（1）鉄筋の腐食面積と腐食度}

図一3 は，暴露開始前に $0.2 \sim 0.3 \mathrm{~mm}$ 幅のひびわれ を生じさせて暴露した無処理はりと，これと同一の荷重 で曲げひびわれを導入したライニングはりより取り出し た鉄筋の腐食面積率と腐食度を示す。ここで示している 值は，2 本のはりより取り出した 4 本の鉄筋の最大值と 最小値および平均值であって, 無処理はりの腐食面積率 に比ベ，ライニングはりの腐食面積率はいずれのかぶり の場合にも著しく減少していることがわかる，一方，腐 食度をみると，ライニングはりの場合が無処理はりの $1 / 2$ 程度の值を示し, 同様にポリマーセメントモルタル ライニングの優れた防食効果が認められる。 ライニング はりの腐食は，すべて暴露前に導入したひびわれの部分 に発生しており，いずれのかぶりの場合にもひびわれ部 以外に鉄筋の腐食は認められなかった。このことは，ラ イニングなどによってコンクリート表面に防食層を設け る 2 種防食の場合には，防食層に欠陥を作らないことが 重要であることを示している.

図一4 は，鉄筋腐食の進行状態と腐食面積率との関係 を示したものであって，腐食面積率の值は同一条件の 2 本のはりょり取り出した 4 本の鉄筋の平均值である.こ の図は，かぶりが $2 \mathrm{~cm}$ の場合のものであるが，無処理 はりの腐食面積率は暴露期間とともに大きくなり, 暴露 期間 5 年では, $60 \%$ 以上の腐食面積率を示す鉄筋もあ る.これに対して，ライニングはりでは，暴露期間 1 年 以降における腐食の進行は比較的緩やかである。ライ二 ングはりの腐食箇所は, 前述したように, 暴露前の曲げ 載荷によって，はりのスパン中央付近に生じた $1 \sim 2$ 本 の比較的大きな幅のひびわれの部分に限定されていたも のである。これらの図から明らかなことは，ポリマーセ メントモルタルをライニングしたコンクリートはりを海 洋飛沫帯のようなきわめて厳しい腐食環境下に 5 年間暴 露した場合でも，鉄筋の腐食はごくわずかしか増加して いないことである.

\section{（2）コンクリート中への塩化物の浸透性状}

図一 5 は，ライニングはりについて，各暴露期間にお けるコンクリート中への塩化物の浸透状況を示す.

ここで示しているライニング部分の塩化物は，ライニ ング部分全厚の平均塩化物含有率である。暴露期間の経 過とともに，このライニング部分での塩化物の増加は認 められるものの，ライニングによってコンクリート中へ の塩化物の浸透をほぼ完全に阻止していることがわか る.また，図一 6 は暴露期間 5 年での塩化物の浸透性状 を，無処理はりと比較したものである.この図からも，
ライニングの塩化物遮蔽性能が優れていることがわか る.

（３）EPMA の面分析による塩素および炭素の分布 状況

前述したように, 塩化物の遮蔽効果をコンクリートは りの全断面にわたって観察するとともに，ライニングに

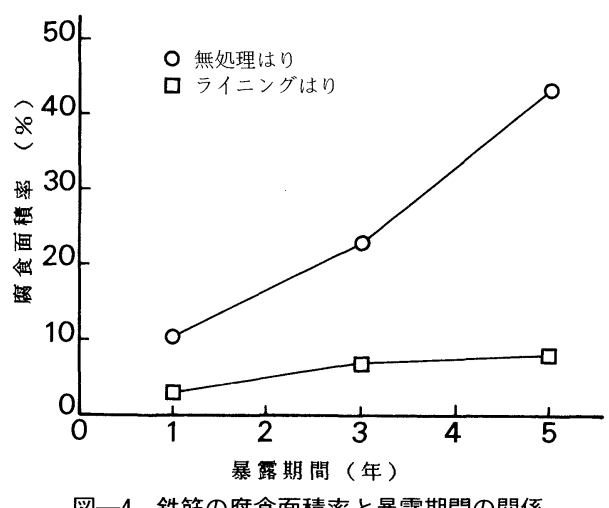

図一4 鉄筋の腐食面積率と暴露期間の関係

(かぶり $2 \mathrm{~cm}$ の場合)

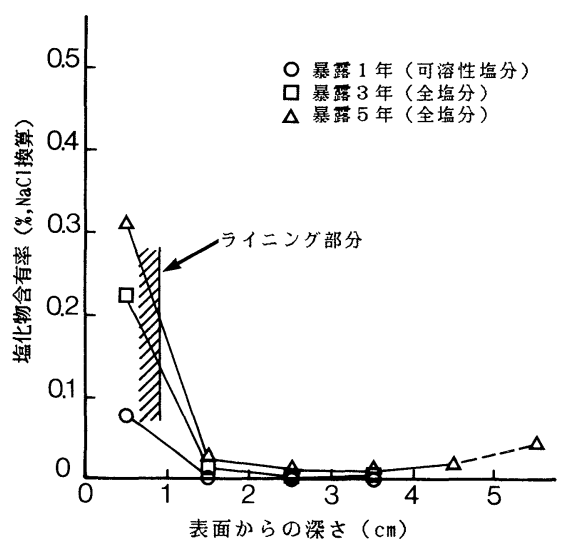

图一5 暴露期間による塩化物含有率の变化

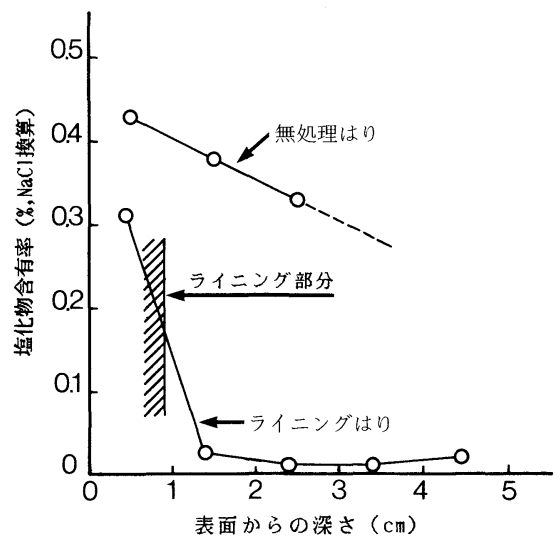

図一 6 コンクリート中への塩化物の浸透性状 (海洋暴露 5 年の場合) 


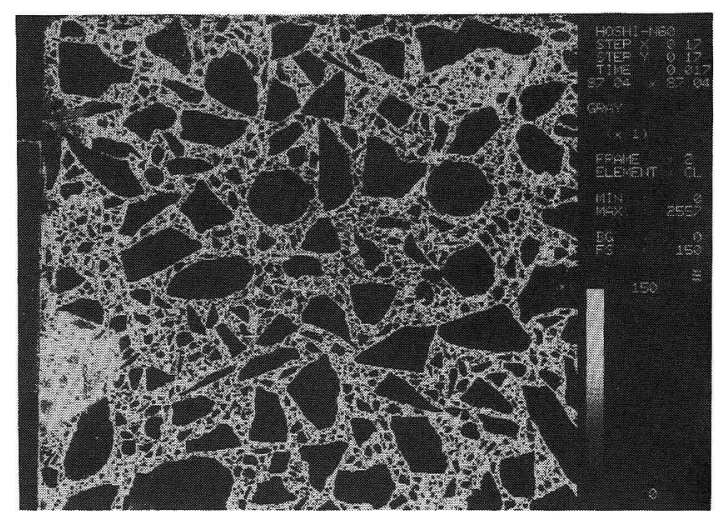

写真一2 EPMAの面分析による塩素の分布

(無処理コンクリートはり断面)

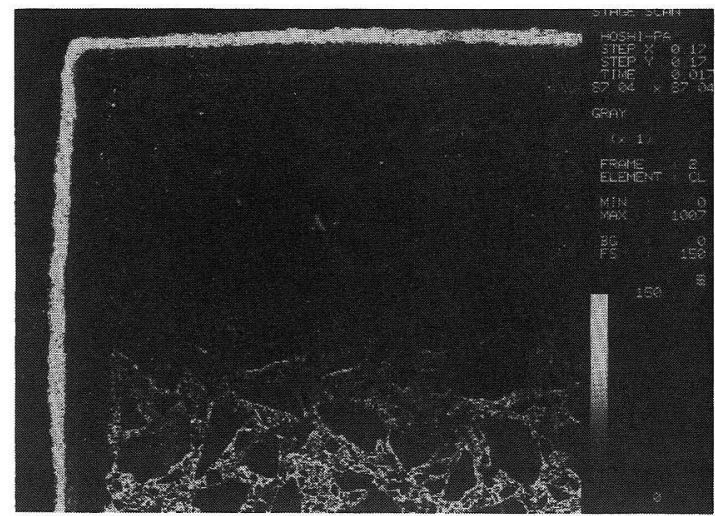

$1 \longleftarrow$ ライニング部分

写真一3 EPMAの面分析による塩素の分布

(ライニングコンクリートはり断面)

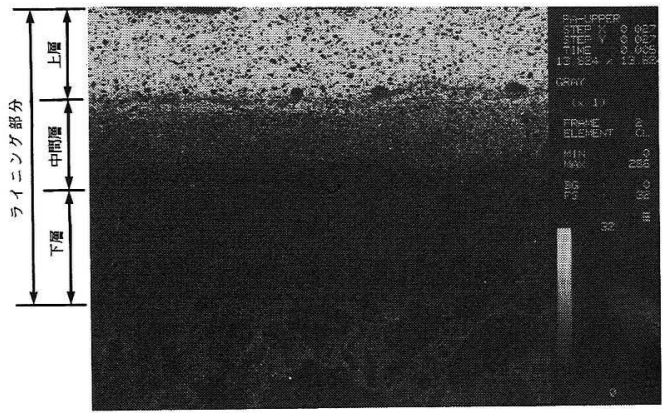

写真一4 EPMAの面分析によるポリマーセメントモルタルラ イニング層における塩素の分布

よる塩化物の遮蔽効果を確認するために EPMAによる 面分析を行った。

写真一 2 は無処理はり, 写真一 3 はライニングはり断 面における塩素の分布状態を示す，画面で白く見える部 分は相対的に塩素濃度が高く，暗色になるほど低くなる ことを示している. 写真一-3の下方において塩素濃度が

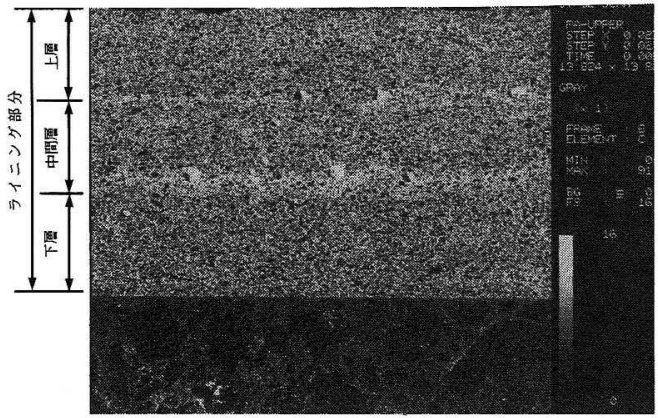

写真一5 EPMAの面分析によるポリマーセメントモルタルラ イニング層における炭素の分布

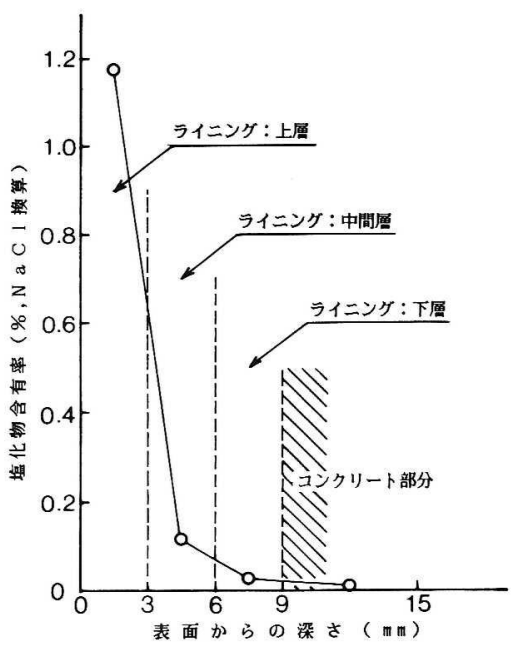

図一7 ライニングの塩化物遮蔽効果（海洋暴露 5 年の場合）

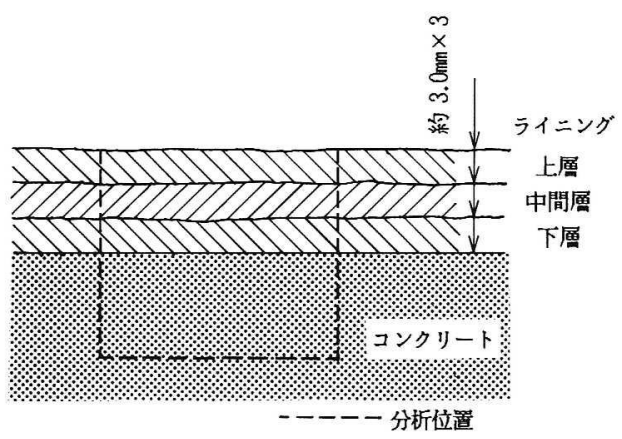

図一8 ライニング断面の模式図と EPMA の分析位置

高くなっている部分は，ライニングを施していない打込 み面から塩化物が浸透したものである.この写真から明 らかなように，ポリマーセメントモルタルのライニング 層が塩化物のコンクリート内部への浸透を効果的に遮蔽 している.

写真一 4 は図一8に示すライニング層部分における塩 素の分布状態を示したものであって,この写真をみると， 


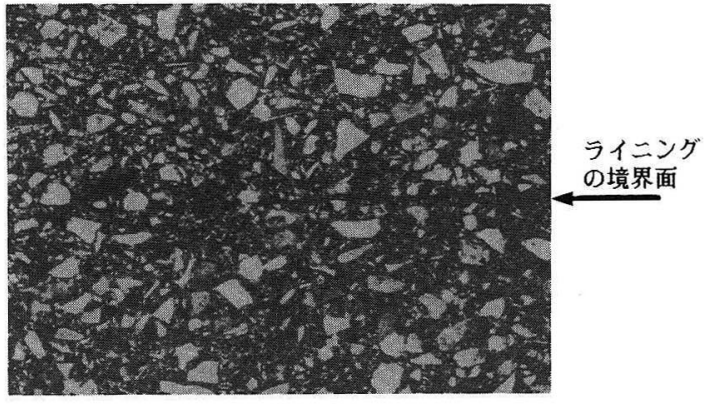

(a) 単ニコル

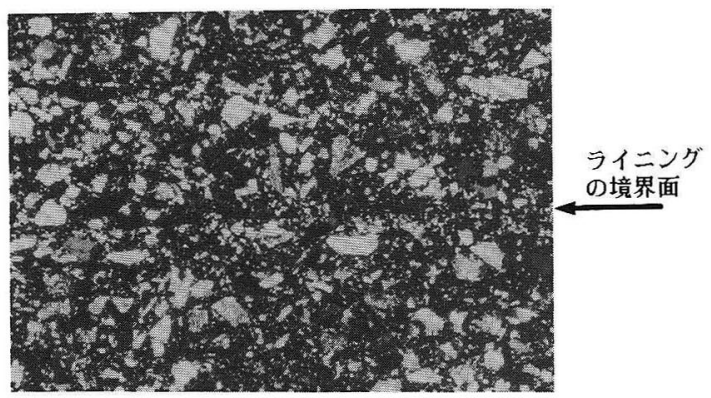

(b) 直交ニコル

写真一 6 ライニング層の偏光顕微鏡写真 $(\times 40)$

塩素濃度は最上層において最も高く, 中間層では下層部 に向かって低下し，最下層部，つまり，コンクリートと の界面の層では，この層の表面付近において完全にバッ クグランドのレベル，すなわち，塩素の浸透がない状態 になっている。図一6および図一7はおのおの写真-2 3 , 与真一 4 に該当する部分の塩素濃度の化学分析結果 であるが，EPMAによる面分析結果と良く対応してい る.

上述のような塩化物の遮蔽効果は, ポリマーセメント モルタルのライニングを 3 層に分けて施工したことと密 接に関係している.すなわち，塩化物の浸透はほとんよ゙ 最上層にとよ゙まっており，中間層にわずか浸透している が,最下層部の表面では完全に遮断されているのである. 何故に塩素の浸透がこのようなライニングの層状構造に よって支配されるのかを検討するために，同じく EPMA によって炭素の分布状態を調べたものが写真一 5 である。

使用したポリマーの主成分は炭素, 酸素, 水素および 窒素であるので，炭素の多い部分にはポリマーが多く存 在すると考えてよい. したがって，この図において，2 本の連続した白色の線状にみえる部分には多くの炭素が 存在することになる.しかし，炭酸化によって炭素の濃 度が高くなる場合も想定される。そこで，この部分の偏 光顕微鏡観察を行った. 写真一6はとの結果であるが, 単ニコル像では矢印で示した部分に線状の組織がみえ， この部分が直交ニコルでは暗くなっており, 非晶質と

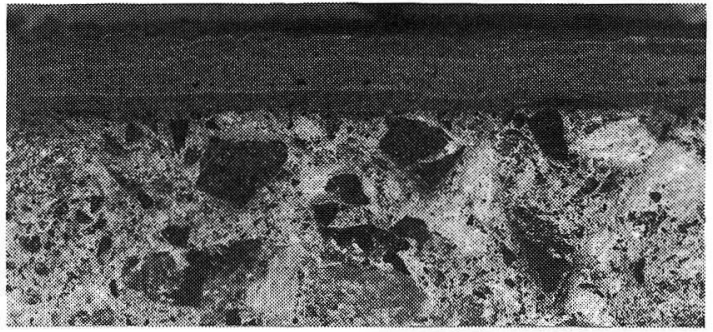

写真一7 ポリマーセメントモルタルライニングの断面

なっていることがわかる.すなわち，この部分は緻密な ポリマーフィルムが形成されていることを示しており, これが塩化物を効果的に遮蔽しているものと考えられ る.

このような緻密なポリマー組織が形成される機構に関 しては, ポリマーセメントモルタルの硬化機構と各層の 施工において，1 つの層を施工してから次の層を施工す る時間よの関係が重要な要因となる.

本研究のライニングの場合, まず下層部を施工してか ら 18 時間湿空中に保存した後, 中間層を施工し, その 後 24 時間湿空中に保存してから上層を施工している.

一般に, ポリマーセメントモルタルにおいては, 薄層 に施工すると表面からの水分の蒸発に伴い, ポリマー ディスパージョンの微粒子が表層部に集まり, 緻密なポ リマーフィルムを形成しやすいといわれている．写真一 5 にみられるポリマーフィルムの層は以上のような機構 によって生じたものと考えられる。このような緻密なポ リマー組織の存在は, 写真一7に示すようなライニング の破断面の観察によっても確認することができる.

\section{（4）コンクリートのひびわれと鉄筋腐食}

図一9は，コンクリートのひびわれの経時変化と暴露 期間 5 年で解体したコンクリートはり中より取り出した 鉄筋の腐食位置の概略を下方に示す，図中の死色部分は ごく表面に発生した点状のさびであり，黒色部分は鉄筋 の断面減少を伴うような腐食箇所である.

ポリマーセメントモルタルのライニングを施したはり の場合，鉄筋の腐食は認められるものの，暴露前に導人 したひびわれのパターンは 5 年経過後でもほとんど変化 していないことがわかる. 一方, 無処理のはりの場合に は，暴露期間 1 年よりコンクリートの表面に鉄筋位置に 沿った縦ひびわれが発生し, 暴露期間 5 年では, コンク リート片のはく落も見受けられ，鉄筋の腐食が，ほぼ全 面にわたって生じていたものもあった.

（5） ライニングの接着強度ならびに酸素の拡散係数

表一 3 は, 海洋飛沫带における 5 年間の暴露を通じて, ポリマーセメントモルタルライニングがどの程度劣化し たかを調ベる 1 つの目安として，ライニングのコンク リートとの接着強度試験を行った結果である. 破壊状況 


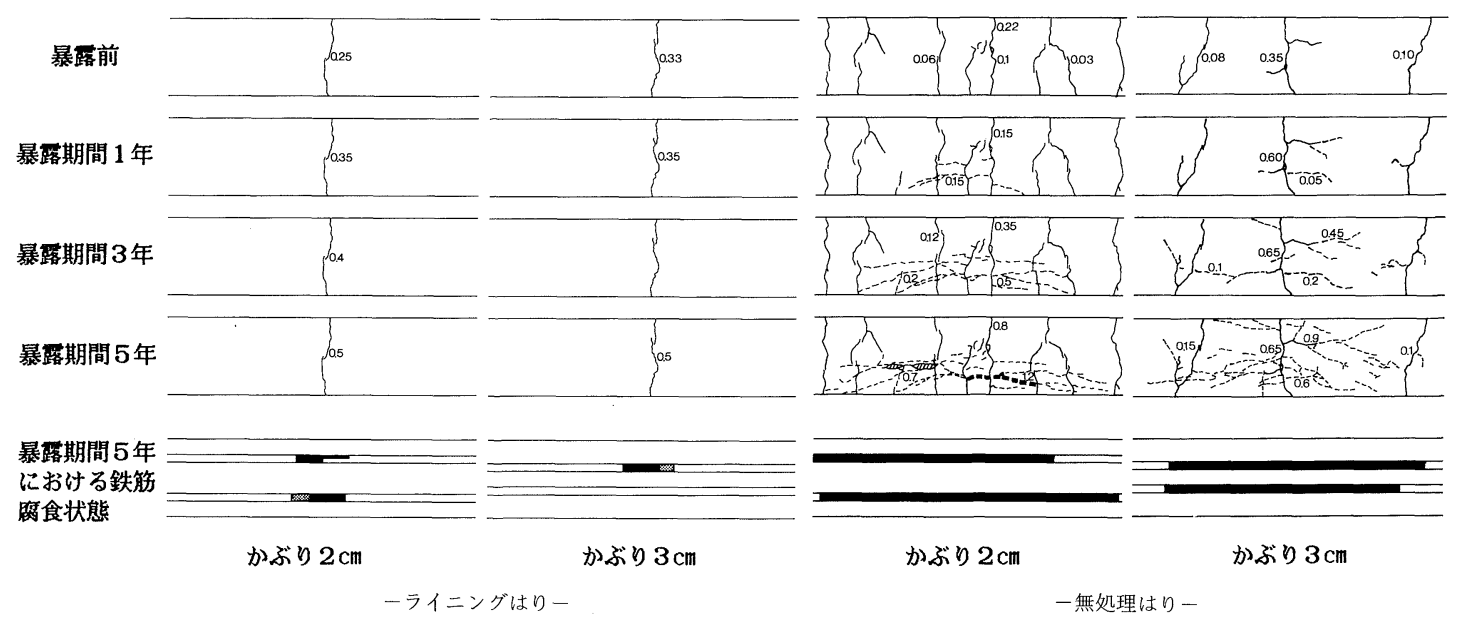

図一9＼cjkstart供試体表面のひびわれの経時変化と鉄筋腐食

表一3 ポリマーセメントモルタルライニングの接着強度

\begin{tabular}{|c|c|c|c|}
\hline $\begin{array}{l}\text { 暴露期間 } \\
\text { (年) }\end{array}$ & $\begin{array}{l}\text { 接着強度 } \\
\left(\mathrm{kgf} / \mathrm{cm}^{2}\right)\end{array}$ & $\begin{array}{c}\text { 平均接着強度 } \\
\left(\mathrm{kgf} / \mathrm{cm}^{2}\right)\end{array}$ & 破塤状況 \\
\hline \multirow{3}{*}{ 暴露開始時 } & 24 & \multirow{3}{*}{27} & \multirow{3}{*}{$\begin{array}{l}\text { すべてコンクリート } \\
\text { 部分で破裹 }\end{array}$} \\
\hline & 26 & & \\
\hline & 30 & & \\
\hline \multirow{3}{*}{1 年 } & 28 & \multirow{3}{*}{30} & \multirow{3}{*}{$\begin{array}{l}\text { すべてコンクリート } \\
\text { 部分で破滖 }\end{array}$} \\
\hline & 30 & & \\
\hline & 33 & & \\
\hline \multirow{3}{*}{ 3年 } & 38 & \multirow{3}{*}{34} & ライニング部分で破壊 \\
\hline & 28 & & 混合破堙 \\
\hline & 37 & & 混合破壊 \\
\hline \multirow{3}{*}{ 5年 } & 50 & \multirow{3}{*}{50} & コンクリート部分で破俵 \\
\hline & 53 & & 混合破壊 \\
\hline & 48 & & 混合破壊 \\
\hline
\end{tabular}

注）混合破壊とは，コンクリートとライニングの両方が破断した状態をいう

からも明らかなように, 暴露 1 年までは, いずれもコン クリート部分において破壊しており，3 年以降になると， ライニング部分で破壊する場合もあるが, 大半は同じ破 断面内にコンクリート部分の破壊とライニング部分の破 壊がモザイク状に生じている. また，見掛けの平均接着 強度の値も暴露期間の経過とともに増大していることか ら, 以上のような暴露条件におけるライニングの耐久性 は優れていると考えられる.なお，暴露期間 5 年におけ る平均接着強度が, 無処理はりの場合 (平均接着強度 $=$ $\left.54 \mathrm{kgf} / \mathrm{cm}^{2}\right)$ とほぼ同程度の大きな值を示した原因につ いては, ライニング中のポリマー分のコンクリートへの 浸透によって，コンクリートの表層部分が強化され，こ の部分が暴露期間の経過に伴い接着強度の向上に寄与し
たものと予想される. 一般に, コンクリートの補修材と して用いられるポリマー系コーティングの場合の接着強 度は 10 20 kgf $/ \mathrm{cm}^{2}$ であることを考えると，ライニン グのコンクリートとの接着は, 海洋飛沫带のようなきわ めて厳しい腐食環境下に暴露した場合でも, 優れている といえる.

一方，鉄筋の腐食が進行するためには，中性化の鉄筋 近傍への進行または塩化物イオンの侵入によって鉄筋表 面の不動態皮膜が破壊された後, 酸素の供給が活発に行 われることが必要である. 酸素の供給の度合は鉄筋を取 り巻いている環境（一般にはコンクリート, 本論文の場 合にはライニングが加わる) の酸素拡散係数によって定 量的に表わすことができる. すなわち，ポリマーセメン トモルタルライニングを行っても, これにコンクリート から誘発された貫通ひびわれが生じた場合には, その直 下の鉄筋部分から腐食を生じることは, 図一3および図 一4から明らかである。しかし，これらの図はまた，無 処理供試体に比べてライニング供試体の場合には腐食速 度が小さいことを示している. ここで, 鉄筋のひびわれ 部分に腐食電池のアノードが，その周辺部分にカソード が形成されていると考えれば，ライニングの存在がカ ソードへの酸素の供給を制御する場合は, 鉄筋の腐食速 度は小さくなると考えられる. ポリマーセメントモルタ ルライニングの酸素拡散係数は普通コンクリートのそれ に比べて小さいことが指摘されているが3)，これを確認 するために暴露期間 5 年間のライニング供試体のライ二 ング部分を含む厚さ約 $20 \mathrm{~mm}$ の試験片を切り出し, 拡

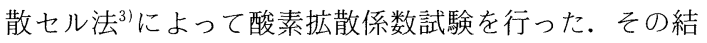
果, ライニング供試体から採取した試験片による拡散係 数は $0.2 \sim 0.4 \times 10^{-4} \mathrm{~cm}^{2} / \mathrm{s}$ ，これに対応する無処理供試 体からの值は $3 \sim 4 \times 10^{-4} \mathrm{~cm}^{2} / \mathrm{s}$ となり，ポリマーセメ 
ントモルタルライニングが酸素拡散性状の面でも鉄筋の 防食に寄与していることが確かめられた。

\section{4. 結論}

海洋環境下に建設される鉄筋コンクリート構造物を対 象とした, ポリマーセメントモルタルのライニングの防 食効果については，これまでほとんど明確にされていな かったが， 5 年間にわたる暴露試験の結果から,この種 のライニングの優れた耐久性を明らかにするとともに, 塩化物の遮蔽性能を明らかにした。 また，ライニングの 塩化物遮蔽機構に関しては, EPMA の面分析の結果か ら層状施工が重要な役割を果たしていることを確認し た。
謝辞：EPMA による試料面の分析を実施して頂 いた東京大学生産技術研究所第 5 部の白木亮司助手，ポ リマーディスパージョンを提供して頂いた恒和化学工業 (株),ならびに暴露試験にご協力を頂いた大成建設(株) 技術研究所に深甚の謝意を表する次第である.

\section{参 考 文 献}

1）小林·星野: 生産研究, Vol. 41, No. 8, 673, 1989.

2）小林·白木 - 星野: 生産研究, Vol. 41, No. 10, 802, 1989.

3）小林・出頭：各種セメント系材料の酸素の拡散性状に関 する研究, コンクリート工学, Vol. 24, No. 12, pp.91〜 106, 1986. 12 .

(1990.2.27 • 受付) 